\title{
The ubiquitous hyaluronan: Functionally implicated in the oviduct?
}

Heriberto Rodriguez-Martinez, P. Tienthai, Mohammad Atikuzzaman, Alejandro Vicente

Carrillo, Marie Rubér and Manuel Alvarez-Rodriguez

\section{Linköping University Post Print}

\section{Tweet}

N.B.: When citing this work, cite the original article.

Original Publication:

Heriberto Rodriguez-Martinez, P. Tienthai, Mohammad Atikuzzaman, Alejandro Vicente Carrillo, Marie Rubér and Manuel Alvarez-Rodriguez, The ubiquitous hyaluronan: Functionally implicated in the oviduct?, 2016, Theriogenology, (86), 1, 182-186.

http://dx.doi.org/10.1016/j.theriogenology.2015.11.025

Copyright: Elsevier

http://www.elsevier.com/

Postprint available at: Linköping University Electronic Press

http://urn.kb.se/resolve?urn=urn:nbn:se:liu:diva-130123

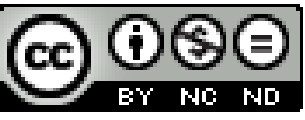


The ubiquitous hyaluronan: functionally implicated in the oviduct?

\section{H Rodriguez-Martinez ${ }^{*}$, P Tienthai ${ }^{2}$, M Atikuzzaman¹, A Vicente-Carrillo', M Rubér'1, M Alvarez-Rodriguez ${ }^{1}$}

${ }^{1}$ Department of Clinical \& Experimental Medicine (IKE), Linköping University (LiU), Linköping, Sweden; ${ }^{2}$ Department of Anatomy, Faculty of Veteruinary Science, Chulalongkorn University, Bangkok 10330, Thailand.

\section{Abstract}

Hyaluronan (hyaluronic acid) is a simple, non-antigenic, non-sulphated glycosaminoglycan (GAG) present everywhere in the extracellular compartments of the body. Noteworthy, it is highly conserved phylogenetically, from sauropsida to mammals; and plays a plethora of roles from embryonic/fetal development to adult physiological and pathological events, including tumor development. In reproduction, hyaluronan has proven related to initial events as sperm survival, build-up of the sperm reservoir in the oviduct, regulation of sperm capacitation and pre-fertilization to later participate in embryo, fetal and placental development. Synthesis, binding (via the CD44 membrane receptor) and degradation of hyaluronan occur in male and female genital organs, the oviduct being no exception. This review discusses our current knowledge on roles of this ubiquitous GAG on the survival of immunologically foreign spermatozoa in the pig oviduct, a relevant event for fertility. During pre-ovulatory storage in the functional tubal sperm reservoir, spermatozoa are entrapped in a mucus-like tubal fluid. This fluid contains fluctuating levels of hyaluronan, which is synthesized by the lining 
epithelium by HA-synthase 3 (has3). Both hyaluronan and its CD44-receptor are particularly evident in the deep mucosal furrows of the sperm reservoir, where most spermatozoa are embedded in; kept alive, un-capacitated but also undetected by the immune system of the female. Hyaluronan is also present in the seminal plasma, and evidence points out an involvement of hyaluronan and its receptor in the local (tubal and possibly uterine) production of anti-inflammatory cytokines, such as IL-10, pertaining maternal immune tolerance of these foreign cells.

Keywords: hyaluronan; oviduct; sperm reservoir; sperm survival, capacitation, immunity, pig.

*Corresponding author: Prof. Dr. Heriberto Rodríguez-Martínez, Department of Clinical and Experimental Medicine (IKE), Faculty of Health Sciences, Linköping University, Campus US, Lasarettsgatan entrance 64/65, Floor 12, SE-581 85 Linköping, SWEDEN. Tel: +46101032284, Fax: +46-1010334789, E-mail: heriberto.rodriguez-martinez@liu.se

\section{Introduction}

Hyaluronan (hyaluronic acid) is a ubiquitous non-sulphated Glycosaminoglycan (GAG), built by an unbranched linear chain of repeating $\mathrm{N}$-acetyl-D-glucosamine and D-glucuronic acid disaccharide units. Contrary to the other (sulphated)-GAGs, hyaluronan is not covalently attached to a protein core, thus lacking antigenicity. The latter can explain its wide distribution over animal classes. Hyaluronan displays, despite its simple structure, a surprising wide range of roles, physiological or pathological [1]. In either case, the major role is structural and related to the creation and filling up of extracellular matrixes [2], including those of genital tissues or between the granulosa cells of the newly ovulated cumulus-oocyte-complex (COC, [3]). 
Hyaluronan also associates with proteoglycans to form large aggregates, stabilized by hyaluronan-binding link proteins [4]. Hyaluronan thus regulates cell proliferation, migration and invasiveness, a matter of utmost relevance during inflammation, wound healing, tissue development or the formation and spreading of tumours [5]. Moreover, hyaluronan is able to control/modulate cell responses by acting as ligand to specific hyaluronan-membrane receptors [6-8]. Hyaluronan is phylogenetically well conserved and it has been localized in genital organs and their secretions, including the seminal plasma [9-12] and the oviduct fluid (see [16] for a recent review of tubal studies in pigs). Most studies on these secretions have concerned their contents in proteins and glycoproteins (seminal fluid [13], oviduct secretion [14,15]). In the tubal fluid, hyaluronan (and other GAGs) has been studied in relation to the sperm reservoir established after insemination, functional during the entire pre- and peri-ovulatory phase [16]. In this tubal reservoir, spermatozoa are able to survive despite their obvious antigenic nature, with maintained fertilizing capacity until ovulation occurs, being continuously and sequentially delivered to encounter the newly ovulated oocytes [17]. This review discusses our current knowledge on the eventual roles of this ubiquitous GAG on the survival of immunologically foreign spermatozoa in the pig oviduct, a process of utmost importance for fertility in pigs.

\section{Hyaluronan is everywhere, including in genital organs}

Indeed is hyaluronan present in most tissues, and genital organs are not exception [18]. Both the connective tissue and the epithelia lining the lumen of the ducti epidydimides, the seminal vesicle, prostate and bulbourethral glands contain hyaluronan [9]. Moreover, hyaluronan was even localized in the luminal content of the sexual accessory glands, which obviously confirms the origin of the hyaluronan present in the seminal plasma [10-12]. Noteworthy, the levels of 
hyaluronan in seminal plasma appeared lower in normal semen samples, to increase with low sperm count and increasing proportions of morphological sperm defects.

Hyaluronan is also clearly present in the female genital tract, in the endocervix and endometrium and particularly the muscular layers of the internal genital tract [19-21]. In the oviduct, hyaluronan is located in the connective tissue as well as in specific areas of the lining epithelium. In particular, hyaluronan is present in the deep mucosal furrows of the functional sperm reservoir [22,23] areas where spermatozoa are stored during the pre-ovulatory stage of oestrus. Within this pre-ovulatory interval, the tubal lumen at the ad-uterine segment is clotted by a very conspicuous mucous oviductal fluid that virtually obliterates the narrow, quasi virtual tubal lumen [24,25]. Such mucus contains the highest hyaluronan-levels recorded in the luminal fluid, concentrations that decrease after ovulations [22], when the mucus appears more fluid [23]. Both hyaluronan synthase (Has3), hyaluronan-binding proteins (HABP) and specific membrane receptors (CD44) are also present in the epithelial lining, particularly in the tubal sperm reservoir [26,27], defining that hyaluronan production on-site occurs with an autocrine relation to the lining epithelia and -probably- the subjacent lamina propria.

\section{The stored tubal spermatozoa and their relation to the tubal fluid}

In the pig, most spermatozoa stored in the pre-ovulatory functional tubal sperm reservoir (e.g. the utero-tubal junction and the adjacent first caudal portion of the isthmus), are seemingly immotile and depict normal ultrastructure during the long pre-ovulation period [28,29]. These spermatozoa remain in the pre-ovulatory functional sperm reservoir for most of the time of estrus and definitely do not readily migrate towards the infundibulum immediately after they are inseminated [29]. Moreover, far from all hereby stored spermatozoa contact the lining 
epithelium, an axiom proposed by others (using in vitro methods) to be a prerequisite to their arrest in the pre-ovulatory functional sperm reservoir. In vivo, most spermatozoa simply remain embedded in the mucus-like tubal fluid [24]. Our own experimental evidence, obtained in vivo by way of the flushing of specific tubal segments at well-defined stages of standing oestrus (pre-, peri- or immediately post-spontaneous ovulation), indicated that most boar spermatozoa retained in the pre-ovulatory functional sperm reservoir during the period from 10-8 $\mathrm{h}$ before ovulation to 8-10 h after ovulation were not considered as undergoing capacitation (monitored via Merocyanine-540 loading) [23], except for a significant increase (on the order of 10\%) in the percentage of sperm capacitation after ovulation [30]. Thus, the conclusion was that the tubal fluid in the pre-ovulatory functional sperm reservoir delayed capacitation in vivo rather than promote it. In vitro, hyaluronan improves sperm motility in a dose-dependent manner [31,32]. Hyaluronan has also been considered as a proper additive for cryopreservation, mostly owing to its stabilizing features on the plasma membrane [33], or its capacity as an antioxidant $[34,35]$. However, at doses similar to those found in the porcine oviduct fluid, exogenous hyaluronan does not appear effective for cryosurvival after conventional freezing [36]. Hyaluronan also modulates sperm capacitation, either delaying [37] or preventing induction of capacitation patterns in vitro (as seen using a chlortetracycline [CTC] assay) e.g. without inducing acrosome exocytosis or cell death $[38,39]$. The concerted evidence emanated from experimental findings, albeit without explanation of the mechanisms behind, all converse to conclude that immersion in hyaluronan-containing (tubal) fluid is beneficial for sperm survival, maybe simply delaying the permissive capacitation process [23,40]. Further mechanistic studies are thus needed to discern how we can manipulate sperm stability using hyaluronan.

\section{Spermatozoa interact with hyaluronan via the transmembrane receptor CD44}


Hyaluronan interacts with the surface of epithelial cells also via CD44 present on most epithelial cells including the pig pre-ovulatory functional sperm reservoir [26], granulosa and cumulus cells [41]. CD44 is the most widely distributed and best characterized hyaluronanreceptor and thus considered as the major receptor on most cell types explored thus far [4]. CD44 acts as an adhesion receptor and can mediate rolling, attachment and migration of cells on a hyaluronan substratum. In addition, as has been demonstrated for all of the other major adhesion receptors, binding of ligand can result in CD44-mediated transduction of intracellular signals leading to changes in cell proliferation, survival and differentiation $[7,8,42]$. However, although most cell types express CD44, not all cells bind hyaluronan. Spermatozoa from human, boars or bulls contain CD44 in their plasma membrane $[26,43,44]$ and should thus bind to tubal fluid hyaluronan as they do to solid state hyaluronan-depots (i.e. the PICSI Sperm Selection device, USA [45]). This hyaluronan-binding method, used to define in vitro the degree of "normality" of single spermatozoa seems to trap only mature spermatozoa that are able to react with the hyaluronan and to depict high DNA integrity as well as some degree of hyperactivated-like motility pattern. Although the technique was primarily designed to select best spermatozoa for ICSI in human, it was later used for stallion spermatozoa [46], those spermatozoa were not only mature but even had intact chromatin $[47,48]$ although being unselected for normal morphology [49]. The findings indicate a functionally-active, hyaluronan-adhesive form of CD44 that seems -indirectly- to exist in spermatozoa of several species. It is expected that more studies attempt to determine the crucial role of CD44 as a suitable receptor/marker for andrological diagnosis and fertility assurance.

\section{Does hyaluronan influence the immune response to semen?}


Cancer cells promote a transition from homeostatic to a reactive, inflammatory remodeled surrounding extracellular matrix, including hyaluronan where hyaluronan fragments appear to be biologically active, of pro-inflammatory nature, activating signal pathways that promote survival of tumor cells, their migration and invasiveness [50,51]. Hyaluronan is, however, highly dependent on the presence of CD44 in the cells, particularly in cancer stem cells, that survive immune attacks [52,53]. Interestingly, hyaluronan has also shown capacity to induce pro-inflammatory and pro-fibrotic cytokines [54], and to contribute to leukocyte recruitment from the blood circulation [55], indicating an interacting role in immunological systems [56]. Lipopolysaccharide (LPS) and some cytokines (as tumor necrosis factor, TNF) can induce formation of a hyaluronan-adhesive form of CD44 [57]. Such cell surface receptor CD44 is needed for polymorphonuclear leukocytes to interact and migrate on hyaluronan [58].

As mentioned above, semen, and the seminal plasma in particular, contains measurable amounts of hyaluronan and spermatozoa bear the identifiable trans-membrane receptor CD44. Seminal plasma causes a transient inflammatory reaction in the cervix and uterus of pig (and other species, including human) that conveys to cleanse the lumen from foreign spermatozoa, other cells, microorganisms and seminal plasma proteins. That inflammation is caused by specific seminal plasma proteins (as PSP-I/II, [59]) but also through the entry of seminal plasma-bearing pro-inflammatory cytokines [60]. At the same time, the boar seminal plasma also contains antiinflammatory cytokines [60] as well as it stimulates (in human, via E-type prostaglandins, [61]) the production of cervical and uterine IL-10, a clearly anti-inflammatory cytokine. Such production of IL-10 is also induced from implants delivering hyaluronan [61]). It is therefore tempting to speculate that the sperm survival we register in the pre-ovulatory oviductal functional sperm reservoir, where hyaluronan accumulates in the tubal fluid and specific segments of the lining epithelium, might relate to the non-antigenic nature of hyaluronan. Being 
covered by hyaluronan, spermatozoa can very well be "undetectable" by the immune system of the female. If signaling from sperm molecules/epitopes do not reach the female antigenpresenting cells, then spermatozoa would thus remain undetected. This explanation might sound too simplistic, but the presence of IL-10 in the seminal plasma of fertile boars [60] or the induction of IL-10 secretion by the hyaluronan present in the seminal plasma or the tubal fluid could very well participate in this permissive mechanism for sperm tolerance in the oviduct of pigs. The relevance of this immunological interplay, initiated by the deposition of semen (or seminal plasma) on subsequent fertility is very high, and studies ongoing to decipher its mechanism.

\section{Concluding remarks}

The lumen of the pre-ovulatory functional sperm reservoir (in the utero-tubal junction-caudal isthmus) of oestrous pigs contains a mucus-like fluid in where spermatozoa are entrapped. Such fluid is rich in hyaluronan, which is also present (and synthesized) by the lining epithelium. This fluid is not only building up the pre-ovulatory functional sperm reservoir, but also maintains sperm survival and delays destabilization processes at the plasmalemma i.e. sperm capacitation. Moreover, spermatozoa escape detection or attack by the female immune system while inside the oviductal lumen, tentatively by a hyaluronan coating that prevents detection of the immunologically foreign spermatozoa by the female immune system or by the presence of anti-inflammatory cytokines i.e. IL-10 either in the seminal plasma or produced by the oviduct. This interplay would induce a process of female immune tolerance to the parental antigens present in spermatozoa or in the accompanying seminal plasma.

\section{Acknowledgements}


The studies of the authors have been made possible by grants from The Swedish Research Council VR (Vetenskapsrådet) and the Swedish Research Council Formas, Stockholm, Sweden.

\section{References}

[1] Laurent TC, Fraser JR. Hyaluronan. FASEB J 1992;6: 2397-2404.

[3] Yokoo M, Kimura N, Abe H, Sato E. Influence of hyaluronan accumulation during cumulus expansion on in vitro porcine oocyte maturation. Zygote 2008; 16: 309-314.

[4] Day AJ, Prestwich GD. Hyaluronan-binding proteins: tying up the giant. J Biol Chem 2002; 277: 4585-4588.

[5] Misra S, Hascall VC, Markwald RR, Ghatak S. Interactions between hyaluronan and its receptors (CD44, RHAMM) regulate the activities of inflammation and cancer. Front Immunol 2015; 6: art 201, 31pp.s

[6] Turley EA, Noble PW, Bourguignon LY. Signaling properties of hyaluronan receptors. J Biol Chem 2002; 277: 4589-4592.

[7] Ponta H, Sherman L, Herrlich PA. CD44: from adhesion molecules to signaling regulators. Nat Rev Mol Cell Biol 2003; 4: 33-45. 
[8] Thorne RF, Legg JW, Isacke CM. The role of the CD44 transmembrane and cytoplasmic domains in co-ordinating adhesive and signaling events. J Cell Sci 2004; 117: 373-378.

[9] Tammi R, Rönkkö S, Ågren UM, Tammi M. Distribution of hyaluronan in bull reproductive organs. J Histochem Cytochem 1994; 42:1479-1486.

[10] Geipel U, Kropf J, Krause W, Gressner AM. The concentration pattern of laminin. hyaluronan, and aminoterminal propeptide of type procollagen in seminal fluid. Andrologia 1992; 24: 205-211.

[11] Binette JP, Ohishi H, Burgi W, Kimura a, Suyemitsu T, Seno N, Schmid K. The content and distribution of glycosaminoglycans in the ejaculates of normal and vasectomized men. Andrologia 1996; 28: 145-149.

[12] Laudat A, Guechot J, Foucault P, Gibodeau J, Palluel AM. Fibronectin and hyaluronic acid in seminal fluid: relationship with sperm count and percentage of typical forms. Pathol Biol (Paris) 1997; 45: 462-466.

[13] Rodriguez-Martinez H, Kvist U, Ernerudh J, Sanz L, Calvete JJ. Seminal plasma proteins: what role do they play? Am J Reprod Immunol (AJRI) 2011; 66, S1: 11-22.

[14] Avilés M, Gutierrez-Adan A, Coy P. Oviductal secretions: will they be key factors for the future ARTs? Mol Human Reprod 2010; 16: 896-906. 
[15] Ghersevich S, Massa E, Zumoffen C. Oviductal secretion and gamete interaction. Reproduction 2015; 149: R1-R14.

[16] Tienthai P. The porcine sperm reservoir in relation to the function of hyaluronan. J Reprod Dev 2015; 61: 245-250.

[17] Rodriguez-Martinez H. Role of the oviduct in sperm capacitation. Theriogenology 2007; 68: 138-146.

[18] Laurent C, Hellström S, Engström-Laurent A, Wells AF, Bergh A. Localization and quantity of hyaluronan in urogenital organs of male and female rats. Cell Tissue Res 1995; 279: 241-248.

[19] Munakata H, Isemura M, Kodama C, Yosizawa Z. Glycosaminoglycans of porcine uteri. Tohoku J Exp Med 1985; 147: 73-75.

[20] Edelstam GA, Lundkvist OE, Wells AF, Laurent TC. (1991) Localization of hyaluronan in regions of the human female reproductive tract. J Histochem Cytochem 1991; 39:1131-1135.

[21] Raheem KA, Marei WF, Mifsud K, Khalid M, Wathes DC, Fouladi-Nashta AA. Regulation of the hyaluronan system in ovine endometrium by ovarian steroids. Reproduction 2013; 145: 491-504. 
[22] Tienthai P, Kjellén L, Pertoft H, Suzuki K, Rodriguez-Martinez H. Localisation and quantitation of hyaluronan and sulphated glycosaminoglycans in the tissues and intraluminal fluid of the pig oviduct. Reprod Fert Dev 2002; 12: 173-182.

[23] Rodriguez-Martinez H, P Tienthai, K Suzuki, H Funahashi, H Ekwall, Johannisson A. (2001) Oviduct involvement in sperm capacitation and oocyte development. Reproduction 2001; s58:129-145.

[24] Rodriguez-Martinez H, Larsson B, Pertoft H, Kjellén L. GAGs and spermatozoon competence in vivo and in vitro. In: Gametes: Development and function (Lauria A, F Gandolfi, G Enne, L Gianaroli, eds), Serono Symposia, Italy (ISBN-88-85974-37-6) 1998; 239-274.

[25] Johansson M, Tienthai P, Rodríguez-Martínez H. Histochemistry and ultrastructure of the intraluminal mucus in the sperm reservoir of the pig oviduct. J Reprod Dev 2000; 46: 183-192.

[26] Tienthai P, Kimura N, Heldin P, Sato E, Rodríguez-Martínez H. Expression of hyaluronan synthase-3 in porcine oviductal epithelium during oestrus. Reprod Fert Dev 2003; 15: 99-105.

[27] Tienthai P, Yokoo M, Kimura N, Heldin P, Sato E, Rodriguez-Martinez H. Immunohistochemical localization and expression of the hyaluronan receptor CD44 in the porcine oviductal epithelium during oestrus. Reproduction 2003; 125: 119-132.

[28] Rodriguez-Martinez H, Nicander L, Viring S, Einarsson S, Larsson K. Ultrastructure of the uterotubal junction in preovulatory pigs. Anat Histol Embryol 1990; 19: 16-36. 
[29] Mburu JN, Rodriguez-Martinez H, Einarsson S. Changes in sperm ultrastructure and localisation in the porcine oviduct around ovulation. Anim Reprod Sci 1997; 47: 137-148.

[30] Tienthai P, Johannisson A, Rodríguez-Martínez H. Sperm capacitation in the porcine oviduct. Anim Reprod Sci 2004; 80: 131-146.

[31] Huszar G, Willetts M, Corrales M. Hyaluronic acid (sperm Select) improves retention of sperm motility and velocity in normospermic and oligospermic specimens. Fertil Steril 1990; 54: $1127-1134$

[32] Shamsuddin M, Rodriguez-Martinez H, Larsson B. Fertilizing capacity of bovine spermatozoa selected after swim-up in hyaluronic acid-containing medium. Reprod Fertil Dev 1993; 5: 307-315.

[33] Peña FJ, Johannisson A, Wallgren M, Rodriguez Martinez H. Effect of hyaluronan supplementation on boar sperm motility and membrane lipid architecture status after cryopreservation. Theriogenology 2004; 61: 63-70.

[34] Najafi A, Najafi MH, Zanganeh Z, Sharafi M, Martinez-Pastor F, Adelhust H. Cryopreservation of ram semen in extenders containing soybean lecithin as cryoprotectant and hyaluronic acid as antioxidant. Reprod Domes Anim 2014; 49: 934-940.

[35] Sariözkan S, Tunder PB, Büyükleblebici S, Bucak MN, Cantürk F, Eken A. Antioxidative effects of cysteamine, hyaluronan and fetuin on post-thaw semen quality, DNA 
integrity and oxidative stress parameters in the Brown Swiss bull. Andrologia 2015; 47: 138147.

[36] Alvarez-Rodriguez, Rodriguez-Martinez H. Exogenous hyaluronan does not improve cryosurvival of boar spermatozoa. Reprod Domest Anim 2015; 50s2:33-34.

[37] Yeste m, Briz M, pinart E, Sancho S, Garcia-Gil N, Badia E, Bassols J, Pruneda A, Bussalleu E, Casas I, Bonet S. Hyaluronic acid delays boar sperm capacitation after 3 days of storage at $15{ }^{\circ} \mathrm{C}$. Anim Reprod Sci 2008; 109: 236-250.

[38] Rodriguez-Martinez H, Larsson B, Pertoft H. Evaluation of sperm damage and techniques for sperm clean-up. Reprod Fertil Dev 1997; 9: 297-308.

[39] Suzuki K, Asano A, Eriksson B, Niwa K, Shimizu H, Nagai T, Rodriguez-Martinez H. Capacitation status and in vitro fertility of boar spermatozoa: Effects of seminal plasma, cumulus-oocytes-complexes-conditioned medium and hyaluronan. Int J Androl 2002; 25: 8493.

[40] Rodriguez-Martinez H, Saravia F, Wallgren M, Tienthai P, Johannisson A, Vázquez JM, Martínez E, Roca J, Sanz L, Calvete JJ. Boar spermatozoa in the oviduct. Theriogenology 2005; 63: 514-535.

[41] Yokoo M, Tienthai P, Kimura N, Niwa K, Sato E, Rodriguez-Martinez H. Localisation of the hyaluronan receptor CD44 in porcine cumulus cells during in vivo and in vitro maturation. Zygote 2002; 10: 317-326. 
[42] Toole BP. Hyaluronan: from extracellular glue to pericellular cue. Nat Rev Cancer 2004; 4: 528-539.

[43] Huszar G, Ozenci CC, Cayli S, Zavaczki Z, Hansch E, Vigue L. Hyaluronic acid binding indicates cellular maturity, viability, and unreacted acrosomal status. Fertil Steril 2003; 79s3:1616-1624.

[44] Bergqvist AS, Ballester J, Johannisson A, Hernández M, Lundeheim N, RodríguezMartínez H. In vitro capacitation of bull spermatozoa by oviductal fluid and its components. Zygote 2006; 14: 259-273.

[45] Huszar G, Jakab A, Sakkas D, Ozenci CC, Cayli S, Delpiano E, Ozkavukcu S. (2007) Fertility testing and ICSI sperm selection by Hyaluronic acid binding: clinical and genetic aspects. Reprod Biomed Online 2007; 14: 650-663

[46] Colleoni S, Lagutina I, Lazzari G, Rodriguez-Martinez H, Galli C, Morrell JM. New methods for selecting stallion spermatozoa for assisted reproduction. J Equine Vet Sci 2011; $31536-541$

[47] Razavi SH, Nasr-Esfahani MH, Deemeh MR, Shayesteh M, Tavalaee M. Evaluation of zeta and HA-binding methods for selection of spermatozoa with normal morphology, protamine content and DNA integrity. Andrologia 2009; 42: 13-19 
[48] Yagci A, Murk W, Stronk J, Huszar G. Spermatozoa bound to solid state Hyaluronic acid show chromatin structure with high DNA chain integrity: an acridine orange fluorescence study. J Androl 2010; 3:566-572

[49] Petersen CG, Massaro FC, Mauri AL, Oliveira JB, Baruffi RL, Franco JG Jr. Efficacy of hyaluronic acid binding assay in selecting motile spermatozoa with normal morphology at high magnification. Reprod Biol Endocrinol 2010; 8: 149 (7pp)

[50] Schwertfeger KL, Cowman MK, Telmer PG, Turley EA, McCarthy JB. Hyaluronan, inflammation, and breast cancer progression. Front Immunol 2015; 6: 236-41.

[51] Monslow J, Govindaraju P, Pure E. Hyaluronan - a functional and structural sweet spot in the tissue microenvironment. Front Immunol 2015; 6: 23-4.

[52] Bourguignon LY, Shiina M, Li JJ. Hyaluronan-CD44 interaction promotes oncogenic signaling, microRNA functions, chemoresitande, and radiation resistance in cancer stem cells leading to tumor progression. Adv Cancer Res 2014; 123: 255-275.

[53] Chanmee T, Ontong P, Kimata K, Itano N. Key roles of hyaluronan and its CD44 receptor in the stemness and survival of cancer stem cells. Front Oncol 2015; 5: 180-4.

[54] De la Motte CA. Hyaluronan in intestinal homeostasis and inflammation: implications for fibrosis. Am J Gastrointest Liver Physiol 2011; 301: G945-G949.

[55] Kessler S, Rho H, West G, Fiocchi C, Drazba J, de la Motte C. Hyaluronan (HA) deposition 
precedes and promotes leukocyte recruitment in intestinal inflammation. Clin Transl Sci 2008; 1: 57-61.

[56] Siegelman MH, DeGrendele HC, Estess P. Activation and interaction of CD44 and hyaluronan in immunological systems. J Leukoc Biol 1999; 66: 315-321.

[57] Gee K, Kozlowski M, Kumar A. Tumor necrosis factor-alpha induces functionally active hyaluronan-adhesive CD44 by activating sialidase through p38 mitogen-activated protein kinase in lipopolysaccharide-stimulated human monocytic cells. J Biol Chem 2003; 278: 37275-87.

[58] Aziz KA. CD44 mediates polymorphonuclear leukocyte motility on hyaluronan. Saudi Med J 2003; 24: 827-831.

[59] Rodriguez-Martinez H, Saravia F, Wallgren M, Martinez EA, Sanz L, Roca J, Vazquez JM, Calvete JJ. Spermadhesin PSP-I/PSP-II heterodimer induces migration of polymorphonuclear neutrophils into the uterine cavity of the sow. J Reprod Immunol 2010; 84: $57-65$

[60] Barranco I, Rubér M, Perez-Patiño C, Atikuzzaman M, Martinez EA, Roca J, H RodriguezMartinez H. The seminal plasma of the boar is rich in cytokines, with significant individual and intra-ejaculate variation. Am J Reprod Immunol (AJRI) 2015; (In press).

[61] Denison FC, Grant VE, Calder AA, Kelly RW. Seminal plasma components stimulate interlekin-8 and interleukin-10 release. Mol Hum Reprod 1999; 5:220-226. 
[62] Bollyky PL, Vernin RB, Falk BA, Preisinger A, Gooden MD, Nepom GT, Gebe JA. IL10 induction from implants delivering pandreatic islets and hyaluronan. J Diabetes Res 2013; ID 32479, 9pp. 